\title{
REHABILITATION IN ONCOLOGY
}

Kamilova TA ${ }^{1}$, Golota $\mathrm{AS}^{1}{ }^{\otimes}$, Vologzhanin $\mathrm{DA}^{1,2}$, Shneider OV${ }^{1}$, Scherbak $\mathrm{SG}^{1,2}$

1 Saint Petersburg City Hospital № 40, Saint Petersburg, Russia

2 Saint-Petersburg State University, Saint Petersburg, Russia

Current oncology and oncohematology treatment methods allow more patients to successfully survive the disease. However, afterwards, most survivors have to deal with a wide range of symptoms and side effects and need rehabilitation. Personalized rehabilitation programs for such patients employ various methods of physical medicine. Physical activity is an important component of the cancer patients' treatment and rehabilitation. It improves their functional health, specifically physical performance, cognitive function, psychological health, and makes the quality of their lives better. Physical activity increases muscle strength, alleviates the radiation and chemotherapy side effects and relieves fatigue. Personalized exercise programs are employed to monitor patient's condition and exercise tolerance. Physical and cognitive rehabilitative interventions are performed simultaneously as part of interdisciplinary rehabilitative care, so this approach can have a synergistic effect. It is necessary to factor in contraindications when prescribing regular physical activity, exercise and other methods of rehabilitation, otherwise they can lead to clinical complications.

Keywords: cancer, oncology disease, rehabilitation, physical activity, quality of life, muscle strength, fatigue, physical exercises.

Author contribution: Kamilova TA — search and analysis, article text authoring; Golota AS — search and analysis, article text discussion and editing; Vologzhanin DA — article text discussion and editing; Schneider OV, Shcherbak SG — concept development, article discussion; all authors made a significant contribution to concept development and article preparation, they have read and approved the final version thereof before publication.

$\triangle$ Correspondence should be addressed: Alexander S. Golota

Borisova, 9 B, St. Petersburg, 197706; golotaa@yahoo.com

Received: 29.05.2021 Accepted: 12.06.2021 Published online: 21.06.2021

DOI: $10.47183 /$ mes.2021.013

\section{РЕАБИЛИТАЦИЯ В ОНКОЛОГИИ}

Т. А. Камилова ${ }^{1}$, А. С. Голота ${ }^{1}$, Д. А. Вологжанин ${ }^{1,2}$, О.В.Шнейдер ${ }^{1}$, С. Г. Щербак ${ }^{1,2}$

${ }^{1}$ Городская больница № 40, Санкт-Петербург, Россия

${ }^{2}$ Санкт-Петербургский государственный университет, Санкт-Петербург, Россия

Современное лечение онкологических и онкогематологических заболеваний приводит к повышению выживаемости пациентов. Однако большинство выживших пациентов сталкиваются с широким спектром симптомов и побочных эффектов и нуждаются в реабилитации. Индивидуальные программы реабилитации таких больных включают в себя различные методы физической медицины. Физическая активность является важным компонентом в лечении и реабилитации больных онкологическими заболеваниями и улучшает их функциональное здоровье в отношении физической работоспособности, когнитивных функций, психологического здоровья и качества жизни. Физическая активность увеличивает мышечную силу, уменьшает побочные эффекты лучевой и химиотерапии и снижает утомляемость. Для контроля состояния пациента и толерантности к физическим нагрузкам используют индивидуально адаптированные программы физических упражнений. Реабилитационные вмешательства физической и когнитивной направленности выполняются одновременно в рамках междисциплинарной реабилитационной помощи, поэтому такой подход может иметь синергетический эффект. Регулярные физические нагрузки, упражнения и другие методы реабилитации необходимо применять с учетом противопоказаний, в противном случае они могут привести к клиническим осложнениям.

Ключевые слова: рак, онкологическое заболевание, реабилитация, физическая активность, качество жизни, мышечная сила, утомляемость, физические упражнения

Вклад авторов: Т. А. Камилова - поисково-аналитическая работа, написание текста статьи; А. С. Голота - поисково-аналитическая работа, обсуждение и редактирование текста статьи; Д. А. Вологжанин - обсуждение и редактирование текста статьи; О. В. Шнейдер, С. Г. Щербак разработка концепции, обсуждение статьи; все авторы внесли существенный вклад в разработку концепции, подготовку статьи, прочли и одобрили финальную версию перед публикацией.

$\triangle$ Для корреспонденции: Александр Сергеевич Голота ул. Борисова, д. 9 Б, г. Санкт-Петербург, 197706; golotaa@yahoo.com

Статья получена: 29.05.2021 Статья принята к печати: 12.06.2021 Опубликована онлайн: 21.06.2021

DOI: $10.47183 /$ mes.2021.013

The term "cancer survivor" dates back to the 1980s, but today the numbers of cancer survivors are growing almost exponentially. Many people who have had cancer experience difficulties in their daily life, as about $50 \%$ of them suffer one or more concomitant chronic diseases caused by cancer or its treatment. Some late symptoms may be caused by surgery, radiation therapy, or chemotherapy. In this connection, the number of studies dedicated to rehabilitation of cancer patients is growing, with some of them covering pre-surgery rehabilitation aimed at raising the chances of survival $[1,2]$. Regular physical activity is an important component of rehabilitation of such patients: it improves their functional state, physical performance, mental health and quality of life. It is imperative to minimize the functional impairments and disabilities that such people have to deal with during and after the treatment, and to promote their reintegration into society. This goal requires a coordinated team of physiotherapists, physical therapists and occupational therapists who are familiar with the unique needs of this patient group.

Cancer patients should be informed about rehabilitation, especially about physical therapy (exercise therapy), from the moment of diagnosis. Understanding the vital importance of ability to work, cancer survivors are highly motivated to return to their jobs, since many of them are able and willing to work [3].

\section{Rehabilitation in pain management. Exercise therapy}

Debilitating pain is one of the most common and persistent problems faced by cancer patients and cancer survivors, 
with 55\% of them experiencing it during treatment and $40 \%$ thereafter. Currently, pharmacotherapy is the standard approach to cancer pain management. Both patients and many healthcare providers are unaware of the potential benefits of rehabilitation in managing pain during and after cancer treatment. Rehabilitation of cancer patients relies on interdisciplinary cooperation aimed at functional optimization and pain relief. Accurate diagnosis of pain is a critical step in clinical decision making [4]. Sensitization of the central nervous system is added to the primary causes of pain. In this case, the pain is associated not with tissue damage but with altered pain modulation that generates nocyplastic pain (pain arising from altered nociception), which can alter the response to both specific and general exercise therapy. Adaptation of rehabilitation methods to the prevailing mechanism of pain can increase their effect. The rehabilitation methods, including manual therapy, specific and general exercise therapy, must be applied as part of an interdisciplinary approach to pain management, taking into account the nature of the pain and proper assessment of the results. Individual exercise therapy programs differ in content (exercises for mobilization, stretching, muscle strengthening) and duration (time, frequency and intensity). Manual therapy research in oncology addresses passive joint mobilization and massage therapy. Passive manual mobilization is primarily aimed at restoring the range of motion of the joint. The pain can be relieved through activation of mechanoreceptors and stimulation of fast-conducting nerve fibers. One of the studies has shown the beneficial effect passive mobilization has on the long-term prevalence of locoregional pain when done during the first week after surgery [5].

Physical activity diminishes the side effects of treatment reduces the risk of recurrence of cancer and concomitant cardio-metabolic diseases. Based on the results of three summits that discussed the role of physical therapy, the involvement of physical therapists in solving the problems of noncommunicable diseases, including cancer, has been declared an urgent professional priority [6]. A summary of 53 systematic reviews covering exercise therapy prescribed to populations of cancer patients showed that exercising is beneficial before, during and after treatment of all types of cancer, and it is safe to exercise at any stage of the disease [7]. Personalized exercise programs are employed to control patient's condition and capability to exercise [8]. Fatigability is often associated with pain (and vice versa) and can interfere with regular general exercising. Some cancer treatments have toxic effects on the cardiovascular system, resulting in decreased exercise tolerance. This must be taken into account when compiling an exercise program; ideally, the patient should receive treatment from an interdisciplinary team addressing stress, anxiety and sleep disturbances [9].

A meta-analysis of randomized clinical trials (RCTs) conducted using the European Organization for Research and Treatment of Cancer Questionnaire C30 (EORTC-QLQ-C30) [10] showed that cancer patients and cancer survivors who performed aerobic and/or resistance exercises had the pain significantly less intense. A Cochrane Review summarizes the beneficial effects of general physical activity, including aerobic exercise therapy, resistance training and occupational therapy [11]. The mentioned reviews failed to identify the type of exercise therapy and the specific methods that are most effective for pain relief. The response to exercise varies among patients suffering chronic musculoskeletal pain; it may even lead to hyperalgesia [12]. For arthralgia associated with hormone therapy, which affects up to $50 \%$ of breast cancer (BC) survivors, a combination of aerobic training and muscle strengthening exercises is recommended [13]. A high-quality RCT has shown that 150 weekly minutes of aerobic exercising and strength training can lead to clinically significant pain relief in these patients [14]. Aerobic exercise can neutralize many of the side effects of anticancer therapy and reduce mortality from all types of cancer by increasing the maximum oxygen consumption $\left(\mathrm{VO}_{2}\right.$ max) [8]. Pilates has been included in many rehabilitation practices: it is statistically more effective than other interventions for reducing pain in BC patients [15]. Yoga is also gaining popularity as part of the cancer patients rehabilitation programs, as reflected in a review of 29 RCTs [16]. The authors of this review report exercising improves overall quality of life and reduces fatigue and stress.

The biological mechanism behind the capacity of exercising to reduce mortality and improve overall health is an area of research that is still in its infancy. Changing levels of blood and urine biomarkers associated with cancer can be a manifestation of the beneficial effects of exercise therapy. Such biomarkers enable investigations of the specific physiology and mechanisms through which exercising affects relapse occurrence and cancer progression. According to the results of the analysis of 15 studies (including 12 RCTs) dedicated to blood and urine physical activity biomarkers sampled from cancer survivors [17], moderate intensity exercise therapy (70-85\% of the maximum heart rate and/or 11-13 points on the Borg Scale Rating of Perceived Exertion) has a significant effect on some biomarkers: fasting insulin concentration either decreased or remained relatively stable, but increased in untrained patients; insulin resistance decreased post-exercise with no change in control; the levels of IGFI (insulin like growth factor I), IGFII and IGFBP3 (insulin like growth factor binding protein 3) decreased after 6 months of training and increased in the control group, which translated into a significant difference between the groups. Control group showed growing leptin levels, which went down after exercising. Serum osteocalcin levels remained stable after post-exercise but increased in the control group.

Restrictions in daily activities are associated with increased toxicity of chemotherapy, decreased ability to complete treatment, and decreased overall survival. An RCT studied the effect of outpatient occupational/physical therapy (OT/PT) program developed for elderly functionally impaired cancer patients (65-92 years old) on their functional state [18]; the report states that the OT/PT group participants' social acting, physical functioning and aspiration to activity has increased significantly. Occupational therapy reduces stress in cancer patients, which allows better coping with psychosocial problems and improves functioning.

Thus, exercise therapy is safe and well tolerated by cancer patients both during and after treatment. However, the available data indicate that its analgesic effect is weak.

\section{Breast cancer}

The five-year survival rate for non-metastatic BC exceeds $84 \%$ [19]. However, most BC survivors suffer the consequences of the disease or its treatment: pain, decreased arm muscle strength, lymphedema, chronic fatigue and depression, cachexia, decreased lung capacity and range of motion, decreased health-related quality of life (HRQOL), as well as psychosocial consequences, such as stress and reduced social interactions, functional activity and life roles [20]. The loss of muscle mass and decreased performance capability typical of BC patients translate into passivity and deterioration in health. Therefore, post-surgery rehabilitation gets more attention nowadays. 
Patients who exercise before, during, and after BC treatment are more likely to return to work. Low-intensity aerobic training twice a week is well tolerated even by patients undergoing concurrent radiation or chemotherapy [21, 22].

Breast cancer survivors usually avoid using the affected arm, which worsens the physical condition and should be compensated for by strength exercises, since the loss of muscle mass increases the risk of metabolic and cardiovascular diseases [23]. A workout program helped increase muscle strength by $20 \%$ and reduce perceived fatigue, as well as improve physical, role-related, emotional and social functioning. At the same time, the program while reducing side effects experienced during and after cancer treatments. Results from RCTs support the benefits of starting exercise as early as possible. Training loads induces beneficial responses in other tissues, such as bone. This is especially important for BC patients, who have bone density below normal. Strength training helps prevent further bone loss. Authors of the study recommend including high-intensity strength training sessions in the BC patient rehabilitation programs, such rehabilitation subject to careful examination and monitoring of patients [19].

Breast cancer survivors suffer from shortness of breath and low exercise tolerance. The involvement of lymph nodes drastically reduces the peak expiratory flow rate. Respiratory physical therapy is the main method for preventing these complications. Pulmonary rehabilitation, early mobilization and sputum clearance from the airways have a positive effect on symptoms associated with respiratory complications and improve lung function in $\mathrm{BC}$ patients. The effectiveness of physical therapy in restoring lung function after BC treatment is especially apparent in patients with cancer at advanced stages [24].

\section{Lung cancer}

In oncology, pulmonary rehabilitation (PR) is an interdisciplinary complex treatment aimed at improving postoperative results and alleviating complications in patients that received radiation or chemotherapy [25].

Patients with inoperable lung cancer often have low physical status, low exercise tolerance and are physically passive. A clinical trial of an eight-week at-home PR program designed for lung cancer patients treated non-surgically that implies gradual increase of physical activity has shown that rehabilitation can mitigate the afore conditions and increase the likelihood of successful completion of active lung cancer therapy [26]. A Cochrane review dedicated to rehabilitation/exercise therapy for patients with advanced, inoperable lung cancer supports these findings [27].

The European Society of Thoracic Surgeons' Guidelines for Recovery from Lung Surgery recommend prehabilitation for patients with borderline lung function or reduced exercise tolerance [28].

Patients undergoing chemotherapy for lung cancer or malignant pleural mesothelioma completed an eight-week athome PR program that combined exercise with therapeutic education and psychosocial management. These patients were educated to recognize the dyspnea threshold and advised to do the daily 30-45 minute exercise program at least 5 days a week. The program included endurance training on a bicycle ergometer, muscle strengthening exercises with weights (dumbbells) and elastic resistance bands, walking and stairs climbing. There were no PR side effects observed. The physical activity and anxiety scores improved significantly. Post-PR reevaluation showed a correlation of these results with the somatic status of the patients [29].
A meta-analysis that included 15 RCTs (870 participants in total) studying the effect of breathing exercises on dyspnea, sixminute walking distance, anxiety and depression in lung cancer patients shows a positive effect of such exercises on dyspnea and the six-minute test results, especially post-surgery. The authors propose to introduce breathing exercises into routine clinical practice [30]. The increased long-term survival of lung cancer patients and other benefits of PR prompted the Australian Society of Clinical Oncology to issue the official position that all lung cancer patients should be prescribed exercise as part of standard therapy [31].

\section{Hematologic malignancies}

The conditions peculiar to hematologic malignancy $(\mathrm{HM})$ patients are cytopenia, nausea, vomiting, anorexia, loss of energy, anxiety and depression associated with muscle dysfunction, loss of muscle mass and decreased muscle strength. These symptoms can lead to decreased physical activity and development of the disuse syndrome [32]. A crosssectional, observational study aimed to identify the factors influencing muscle function in HM inpatients; the results of this study show that a rehabilitation intervention designed to increase physical activity and improve the nutritional status (diet therapy) should be considered necessary in the context of improvement of muscle function in HM patients [33].

Lymphoma survivors usually complain of long-term and late side effects of treatment, such as chronic fatigue, pain, muscle weakness, neuropathy, anxiety, depression and deteriorating functionality and quality of life [34-36]. Programs that include exercise and relaxation have a positive effect on and relieve these symptoms. In the context of the Relaxation and Exercise In Lymphoma study, patients practiced a 12-week at-home rehabilitation program [37]. For the majority of lymphoma patients (86\%), at-home rehabilitation after chemotherapy was a positive experience that facilitated recovery. Thus, posttreatment rehabilitation programs designed for $\mathrm{HM}$ patients should include observation, motivation building, exercise therapy and healthy lifestyle recommendations.

\section{Abdominal cancer}

Surgery combined with radiation and/or chemotherapy is the standard approach to abdominal cancers. Malnutrition, decreased physical activity and pain increase the risk of suboptimal healing after surgery. In addition, $70 \%$ of colorectal cancer patients, $10-79 \%$ of prostate cancer patients, $42-70 \%$ of pelvic cancer patients experience symptoms of dysfunctions of pelvic floor (bladder, intestine and reproductive organs) after surgery. To learn the feasibility of interdisciplinary approach to rehabilitation of patients who underwent surgery for abdominopelvic cancer, there was designed a study investigating functional disorders, symptoms of pelvic floor muscle dysfunction, changes in muscle strength and physical activity, anxiety, depression and HRQOL before the rehabilitation and 8 weeks and 6 months thereafter [38].

After surgery for stage I-III colorectal, gynecological or prostate cancer, patients underwent an eight-week training program under the supervision of a physical therapist, physiologist, psychologist and nutritionist. Post-rehabilitation, there were clinically and statistically significant changes identified. The patients' exercise capacity improved, bowel symptoms and depression faded, HRQOL increased immediately after the program was completed and remained at the achieved level after 6 months. Exercise therapy for the 
pelvic diaphragm muscles increases their contractility and improves sphincter control. Thus, oncologic rehabilitation should be considered an integral component of standard care protocols applied in abdominal and pelvic cancer cases [38].

\section{Cancer cachexia and muscle atrophy}

Cancer cachexia causes muscle atrophy and loss of body weight, which accelerates the progression of cancer, worsens treatment outcomes, and decreases chances of survival. Complex treatments, including physical therapy, are used to counteract muscle atrophy. Different types of exercise have different effects: for example, endurance training stimulates oxidative metabolism but does not increase the in muscle mass significantly, whereas resistance exercises lead to muscle hypertrophy. Moderate load resistance exercises are used to prevent muscle atrophy. As the muscle mass decreases, there occurs a structural shift from slow-twitch muscle fibers to fast-twitch muscle fibers. To induce muscle hypertrophy, the magnitude of the load is critical: moderate load training will stimulate only the slow-twitch fibers and not fast-twitch fibers. The decrease in the mass of fatigue-resistant slow-twitch fibers is partly responsible for the exercise intolerance and fatigue often observed in cancer patients. This means that, if the patient's physical condition allows, it is beneficial to advise higher load exercise in order to slow down muscle loss [39].

\section{Rehabilitation of cancer patients: organizational aspects}

Most cancer survivors prefer exercising at home with coordination done by the cancer center's exercise therapy specialists. Regular monitoring of how the patients follow the exercise program promotes a lasting change in their behavior (increases adherence to treatment and recommendations) Thus, rehabilitation in the cancer center followed by the prescribed at-home exercising monitored regularly may be a preferable model of exercise therapy rehabilitation of cancer patients that is further enhanced by a continued information exchange between oncologists and exercise therapy specialists and prompt communication of the treatment results to the medical team. Based on these principles, Canadian rehabilitation therapists have developed and implemented a clinically integrated program "Wellness and Exercise for Cancer Survivors" for patients of a major cancer center. This program capitalizes on the upsides of the in-hospital and athome rehabilitation models, with "home" refers to a variety of exercise environments, including fitness centers and outdoor activities. The program, innovative in its structure, demonstrated the central role of the cancer center in providing supportive care to patients in need thereof. The participants could attend weekly group sessions to practice the exercise technique. For independent exercise, they received a detailed program guidance, resistance bands and gymnastic balls. Follow-ups to reevaluate and adapt the exercise program were scheduled 6, 12, 24, and 48 weeks after the initial examination and exercising prescription. Despite a significant dropout rate, the cancer rehabilitation program showed clinically significant improvements of the functional status and was highly praised by the participants. The functional capabilities and quality of life indicators improved over 6 weeks and increased or persisted for 48 weeks [40].

Currently, there is no standardized curriculum for cancer patient rehabilitation specialists. They are trained mainly through mentoring and at the conferences held by national professional societies, the role of which is extremely important. Palliative care and pain management training programs are an alternative thereto. Although most cancer rehabilitation professionals do not prescribe opiates to their patients, leaving it to palliative care specialists, opiate prescribing guidelines are an important component of cancer rehabilitation curricula [41].

Another discussed topic was the need for information, in particular for dietary advice. A survey of 230 cancer survivors showed that $98 \%$ of the respondents would like to receive additional information after treatment. Upon completion thereof, patients are more likely to find cancer-related information on their own than learn it from medical personnel [35]. Cancer survivors must be allowed a constant contact with health professionals (including via online means of communication) and advice on healthy nutrition and lifestyle [42].

\section{CONCLUSION}

Rehabilitation of cancer patients is a new field that aims to help cancer survivors maintain the best possible physical, social, psychological and professional functioning. It consists of many components, including physiotherapy, physical therapy, occupational therapy, speech pathology treatment, neuropsychological and cognitive rehabilitation, lymphedema and pelvic floor therapy. Although cancer rehabilitation is recognized as an important component of high quality cancer care, most cancer survivors find it problematic to gain access thereto. The time has come, and the medical community has started working on changing this reality [43]. It is important that clinicians were not only aware of the disorders that can arise with the appearance of a malignant tumor or its treatment, but also knew how to apply the principles of rehabilitation in these patients [44]. Physical therapists play an important role in the ongoing care for cancer survivors. Currently, there are five cancer patient rehabilitation training programs offered in the US [45].

The modern concept of cancer treatment integrates rehabilitation procedures throughout, from the diagnosis stage to the observation of surviving patients, enabling control over the expected decline in functional status associated with anticancer therapy. Insufficient awareness of the longterm needs of this category of patients and the benefits of rehabilitation is an important problem in clinical practice [18]. The transformation of the rehabilitation of cancer patients into a standard component of therapy will require considerable effort and perseverance. Although the efficacy of rehabilitation exercise therapy has been generally proven, more research is needed to address its safety in patients with heart failure caused by chemotherapy [46].

\section{References}

1. Minnella EM, Liberman AS, Charlebois P, et al. The impact of improved functional capacity before surgery on postoperative complications: a study in colorectal cancer. Acta Oncol. 2019; 58 (5): 573-8. DOI: 10.1080/0284186X.2018.1557343.

2. West MA, Astin R, Moyses HE, et al. Exercise prehabilitation may lead to augmented tumor regression following neoadjuvant chemoradiotherapy in locally advanced rectal cancer. Acta Oncol. 2019; 58 (5): 588-95. DOI: 10.1080/0284186X.2019.1566775. 
3. Cenik F, Mähr B, Palma S, et al. Role of physical medicine for cancer rehabilitation and return to work under the premise of the "Wiedereingliederungsteilzeitgesetz". Wien Klin Wochenschr. 2019 Oct; 131 (19-20): 455-61. DOI: 10.1007/s00508-019-1504-7.

4. Chimenti RL, Frey-Law LA, Sluka KA. A mechanism-based approach to physical therapist management of pain. Phys Ther. 2018; 98 (5): 302-14. DOI: 10.1093/ptj/pzy030.

5. De Groef A, Penen F, Dams L, et al. Best-evidence rehabilitation for chronic pain part 2: pain during and after cancer treatment. J Clin Med. 2019 Jul 5; 8 (7):979. DOI: 10.3390/jcm8070979.

6. Dean E, Skinner M, Myezwa $H$, et al. Health competency standards in physical therapist practice. Phys Ther. 2019; 99 (9): 1242-54. DOI: 10.1093/ptj/pzz087.

7. Stout NL, Baima J, Swisher AK, et al. Systematic review of exercise systematic reviews in the cancer literature (2005-2017). PM R. 2017; 9 (9S2): 347-84. DOI: 10.1016/j.pmrj.2017.07.074.

8. Keilani M, Kainberger F, Pataraia A, et al. Typical aspects in the rehabilitation of cancer patients suffering from metastatic bone disease or multiple myeloma. Wien Klin Wochenschr. 2019; 131 (21-22): 567-75. DOI: 10.1007/s00508-019-1524-3.

9. Ciuca A, Baban A. Psychological factors and psychosocial interventions for cancer related pain. Rom J Intern Med. 2017; 55 (2): 63-68. DOI: 10.1515/rijm-2017-0010.

10. Nakano J, Hashizume K, Fukushima T, et al. Effects of aerobic and resistance exercises on physical symptoms in cancer patients: a meta-analysis. Integr. Cancer Ther. 2018; 17 (4): 1048-58. DOl: 10.1177/1534735418807555.

11. Lahart IM, Metsios GS, Nevill AM, Carmichael AR. Physical activity for women with breast cancer after adjuvant therapy. Cochrane Database of Systematic Rev. 2018 Jan 29; 1 (1): CD011292. DOI: 10.1002/14651858.CD011292.pub2.

12. Rice D, Nijs J, Kosek E, et al. Exercise induced hypoalgesia in pain-free and chronic pain populations: State of the art and future directions. J Pain. 2019 Nov; 20 (11): 1249-66. pii: S15265900(18)30456-5. DOI: 10.1016/j.jpain.2019.03.005.

13. Nahm N, Mee S, Marx G. Efficacy of management strategies for aromatase inhibitor-induced arthralgia in breast cancer patients: $\mathrm{A}$ systematic review. Asian Pac J Clin Oncol. 2018; 14 (6): 374-82. DOI: 10.1111/ajco.12845.

14. Irwin ML, Cartmel B, Gross CP, et al. Randomized exercise trial of aromatase inhibitor-induced arthralgia in breast cancer survivors. J Clin Oncol. 2015; 33 (10): 1104-11. DOI: 10.1200/ JCO.2014.57.1547.

15. Pinto-Carral A, Molina AJ, de Pedro A, Ayan C. Pilates for women with breast cancer: A systematicreview and meta-analysis. Complementary Ther Med. 2018; 41: 130-40. DOI: 10.1016/j. ctim.2018.09.011.

16. Danhauer SC, Addington EL, Cohen L, et al. Yoga for symptom management in oncology: A review of the evidence base and future directions for research. Cancer. 2019; 125 (12): 1979-89. DOI: 10.1002/cncr.31979.

17. McDermott LA, Murphy MH, McNeilly AM, et al. Biological markers as an outcome measure of exercise in cancer rehabilitation: A systematic review. J Cancer Res Ther. 2018; 14 (2): 267-77. DOI: 10.4103/0973-1482.191036.

18. Pergolotti M, Deal AM, Williams GR, et al. Older adults with cancer: a randomized controlled trial of occupational and physical therapy. J Am Geriatr Soc. 2019; 67 (5): 953-60. DOI: 10.1111/ jgs. 15930.

19. Cešeiko R, Eglïtis J, Srebnijs A, et al. The impact of maximal strength training on quality of life among women with breast cancer undergoing treatment. Exp Oncol. 2019; 41 (2): 166-72. DOI: 10.32471/exp-oncology.2312-8852.vol-41-no-2.13249.

20. Schulz SVW, Laszlo R, Otto S, et al. Feasibility and effects of a combined adjuvant high-intensity interval/strength training in breast cancer patients: a single-center pilot study. Disabil Rehabil. 2018; 40 (13): 1501-08. DOI: 10.1080/09638288.2017.1300688.

21. Mirandola D, Miccinesi G, Muraca MG, et al. Longitudinal assessment of the impact of adapted physical activity on upper limb disability and quality of life in breast cancer survivors from an Italian cohort. Support Care Cancer. 2018; 26 (2): 329-32. DOI: 10.1007/s00520-017-3930-2.

22. Paolucci $\mathrm{T}$, Bernetti $\mathrm{A}$, Paoloni $\mathrm{M}$, et al. Therapeutic alliance in a single versus group rehabilitative setting after breast cancer surgery: psychological profile and performance rehabilitation. Biores Open Access. 2019; 8 (1): 101-10. DOI: 10.1089/ biores.2019.0011.

23. Travier N, Buckland G, Vendrell JJ, et al. Changes in metabolic risk, insulin resistance, leptin and adiponectin following a lifestyle intervention in overweight and obese breast cancer survivors. Eur J Cancer Care. 2018; 27 (4): e12861. DOI: 10.1111/ecc.12861.

24. Kulik-Parobczy I. Evaluation of the effectiveness of physiotherapy in patients after oncological breast cancer treatment based on spirometric indicators. Contemp Oncol (Pozn). 2019; 23 (1): 4751. DOI: 10.5114/wo.2019.82929.

25. Janssen SMJ, Abbink JJ, Lindeboom R, Vliet Vlieland TPM. Outcomes of pulmonary rehabilitation after treatment for nonsmall cell lung cancer stages I to Illa: an observational study. J Cardiopulm Rehabil Prev. 2017; 37 (1): 65-71. DOI: 10.1097/ HCR.0000000000000227.

26. Edbrooke L, Aranda S, Granger CL, et al. Multidisciplinary homebased rehabilitation in inoperable lung cancer: a randomised controlled trial. Thorax. 2019; 74 (8): 787-96. DOI:10.1136/ thoraxinl-2018-212996.

27. Peddle-Mclntyre CJ, Singh F, Thomas R, et al. Exercise training for advanced lung cancer. Cochrane Database Syst Rev. 2019; 2 (2): CD012685. DOI: 10.1002/14651858.CD012685.pub2.

28. Batchelor TJP, Rasburn NJ, Abdelnour-Berchtold E, et al. Guidelines for enhanced recovery after lung surgery: recommendations of the enhanced recovery after surgery (ERASVR ) society and the European Society of Thoracic Surgeons (ESTS). Eur J Cardiothorac Surg. 2019; 55 (1): 91-115. DOI: 10.1093/ejcts/ezy301.

29. Olivier C, Grosbois JM, Cortot AB, et al. Real-life feasibility of home-based pulmonary rehabilitation in chemotherapy-treated patients with thoracic cancers: a pilot study. BMC Cancer. 2018; 18 (1): 178. DOI: 10.1186/s12885-018-4102-6.

30. Liu X, Wang YQ, Xie J. Effects of breathing exercises on patients with lung cancer. Oncol Nurs Forum. 2019; 46 (3): 303-17. DOI: 10.1188/19.ONF.303-317.

31. Steiner MC. Should pulmonary rehabilitation be a standard of care in lung cancer? Thorax. 2019; 74 (8): 725-6. DOI: 10.1136/ thoraxinl-2019-213157.

32. Da Silva JR Jr, Wiegert EVM, Oliveira L, Calixto-Lima L. Different methods for diagnosis of sarcopenia and its association with nutritional status and survival in patients with advanced cancer in palliative care. Nutrition. 2018; 60: 48-52. DOI: 10.1016/j. nut.2018.09.003.

33. Fukushima T, Nakano J, Ishii $\mathrm{S}$, et al. Factors associated with muscle function in patients with hematologic malignancies undergoing chemotherapy. Support Care Cancer. 2020 Mar; 28 (3): 1433-9. DOI: 10.1007/s00520-019-04955-2.

34. Damlaj M, El Fakih R, Hashmi SK. Evolution of survivorship in lymphoma, myeloma and leukemia: Metamorphosis of the feld into long term follow-up care. Blood Rev. 2019; 3: 63-73. DOl: 10.1016/j.blre.2018.07.003.

35. Hackett F, Dowling M. Lymphoma survivors' experiences at the end of treatment. J Clin Nurs. 2019; 28 (3-4): 400-9. DOI: 10.1111/jocn.14658.

36. Raphael D, Frey R, Gott M. Maintaining psychosocial wellbeing for post-treatment haematological cancer survivors: Strategies and potential barriers. Eur J Oncol Nurs. 2019; 38: 36-41. DOI: 10.1016/j.ejon.2018.11.011.

37. Hathiramani S, Pettengell R, Moir $\mathrm{H}$, Younis A. Relaxation and exercise in lymphoma survivors (REIL study). BMC Sports Sci Med Rehabil. 2019; 11: 17. DOI: 10.1186/s13102-019-0127-7.

38. Frawley HC, Lin KY, Granger CL, et al. An allied health rehabilitation program for patients following surgery for abdomino-pelvic cancer: a feasibility and pilot clinical study. Support Care Cancer. 2020 Mar; 28 (3): 1335-50. DOI: 10.1007/s00520-019-04931-w.

39. Hegedus A, Trzaskoma L, Soldos P, et al. Adaptation of fatigue affected changes in muscle EMG frequency characteristics for the determination of training load in physical therapy for cancer patients. Pathol Oncol Res. 2020 Apr; 26 (2): 1129-35. DOI: 10.1007/s12253-019-00668-3.

40. Santa Mina D, Au D, Auger LE, et al. Development, implementation, 
and effects of a cancer center's exercise-oncology program. Cancer. 2019; 125 (19): 3437-47. DOI: 10.1002/cncr.32297.

41. Sharma R, Molinares-Mejia D, Khanna A, et al. Training and practice patterns in cancer rehabilitation: a survey of physiatrists specializing in oncology care. Phys Med Rehab. 2020 Feb; 12 (2): 180-5. DOI: 10.1002/pmrj.12196.

42. Hathiramani S, Pettengell R, Moir H, Younis A. Lymphoma survivors' experience of participation in a home-based intervention post-chemotherapy. Qual Life Res. 2019 Nov; 28 (11): 2951-5. DOI: 10.1007/s11136-019-02244-3.

43. Stubblefield MD, Kendig TD, Khanna A. ReVitalizing cancer survivors - making cancer rehabilitation the standard of care.
MD Advis. Spring 2019; 12 (2): 30-33.

44. Stout NL, Silver JK, Alfano CM, et al. Long-term survivorship care after cancer treatment: a new emphasis on the role of rehabilitation services. Phys Ther. 2019; 99 (1): 10-13. DOI: 10.1093/ptj/pzy115.

45. Yadav RR, Ngo-Huang AT, Ng A, et al. Characteristics of cancer rehabilitation fellowship training programs in the USA. J Cancer Educ. 2018; 33 (6): 1364-7. DOI: 10.1007/s13187-018-1371-3.

46. Hutchison N, Deval N, Rabusch S, et al. Physical therapy based exercise protocol for cancer patients: Evaluating outcomes for cardiopulmonary performance and cancer-related fatigue. PM R. 2019 Feb 6. DOI: 10.1002/pmrj.12128.

\section{Литература}

1. Minnella EM, Liberman AS, Charlebois P, et al. The impact of improved functional capacity before surgery on postoperative complications: a study in colorectal cancer. Acta Oncol. 2019; 58 (5): 573-8. DOI: 10.1080/0284186X.2018.1557343.

2. West MA, Astin R, Moyses HE, et al. Exercise prehabilitation may lead to augmented tumor regression following neoadjuvant chemoradiotherapy in locally advanced rectal cancer. Acta Oncol. 2019; 58 (5): 588-95. DOI: 10.1080/0284186X.2019.1566775.

3. Cenik F, Mähr B, Palma S, et al. Role of physical medicine for cancer rehabilitation and return to work under the premise of the "Wiedereingliederungsteilzeitgesetz". Wien Klin Wochenschr. 2019 Oct; 131 (19-20): 455-61. DOI: 10.1007/s00508-019-1504-7.

4. Chimenti RL, Frey-Law LA, Sluka KA. A mechanism-based approach to physical therapist management of pain. Phys Ther. 2018; 98 (5): 302-14. DOI: 10.1093/ptj/pzy030.

5. De Groef A, Penen F, Dams L, et al. Best-evidence rehabilitation for chronic pain part 2: pain during and after cancer treatment. $J$ Clin Med. 2019 Jul 5; 8 (7):979. DOI: 10.3390/jcm8070979.

6. Dean E, Skinner M, Myezwa $H$, et al. Health competency standards in physical therapist practice. Phys Ther. 2019; 99 (9): 1242-54. DOI: 10.1093/ptj/pzz087.

7. Stout NL, Baima J, Swisher AK, et al. Systematic review of exercise systematic reviews in the cancer literature (2005-2017). PM R. 2017; 9 (9S2): 347-84. DOI: 10.1016/j.pmrj.2017.07.074.

8. Keilani M, Kainberger F, Pataraia A, et al. Typical aspects in the rehabilitation of cancer patients suffering from metastatic bone disease or multiple myeloma. Wien Klin Wochenschr. 2019; 131 (21-22): 567-75. DOI: 10.1007/s00508-019-1524-3.

9. Ciuca A, Baban A. Psychological factors and psychosocial interventions for cancer related pain. Rom J Intern Med. 2017; 55 (2): 63-68. DOI: 10.1515/rijm-2017-0010.

10. Nakano J, Hashizume K, Fukushima T, et al. Effects of aerobic and resistance exercises on physical symptoms in cancer patients: a meta-analysis. Integr. Cancer Ther. 2018; 17 (4): 1048-58. DOI: 10.1177/1534735418807555

11. Lahart IM, Metsios GS, Nevill AM, Carmichael AR. Physical activity for women with breast cancer after adjuvant therapy. Cochrane Database of Systematic Rev. 2018 Jan 29; 1 (1): CD011292. DOI: 10.1002/14651858.CD011292.pub2.

12. Rice D, Nijs J, Kosek E, et al. Exercise induced hypoalgesia in pain-free and chronic pain populations: State of the art and future directions. J Pain. 2019 Nov; 20 (11): 1249-66. pii: S15265900(18)30456-5. DOI: 10.1016/j.jpain.2019.03.005.

13. Nahm N, Mee S, Marx G. Efficacy of management strategies for aromatase inhibitor-induced arthralgia in breast cancer patients: A systematic review. Asian Pac J Clin Oncol. 2018; 14 (6): 374-82. DOI: 10.1111/ajco.12845.

14. Irwin ML, Cartmel B, Gross CP, et al. Randomized exercise trial of aromatase inhibitor-induced arthralgia in breast cancer survivors. J Clin Oncol. 2015; 33 (10): 1104-11. DOI: 10.1200/ JCO.2014.57.1547.

15. Pinto-Carral A, Molina AJ, de Pedro A, Ayan C. Pilates for women with breast cancer: A systematicreview and meta-analysis. Complementary Ther Med. 2018; 41: 130-40. DOI: 10.1016/j. ctim.2018.09.011.

16. Danhauer SC, Addington EL, Cohen L, et al. Yoga for symptom

management in oncology: A review of the evidence base and future directions for research. Cancer. 2019; 125 (12): 1979-89. DOI: 10.1002/cncr.31979.

17. McDermott LA, Murphy MH, McNeilly AM, et al. Biological markers as an outcome measure of exercise in cancer rehabilitation: A systematic review. J Cancer Res Ther. 2018; 14 (2): 267-77. DOI: 10.4103/0973-1482.191036.

18. Pergolotti M, Deal AM, Williams GR, et al. Older adults with cancer: a randomized controlled trial of occupational and physical therapy. J Am Geriatr Soc. 2019; 67 (5): 953-60. DOI: 10.1111/ jgs. 15930.

19. Cešeiko R, Eglïtis J, Srebnijs A, et al. The impact of maximal strength training on quality of life among women with breast cancer undergoing treatment. Exp Oncol. 2019; 41 (2): 166-72. DOI: 10.32471/exp-oncology.2312-8852.vol-41-no-2.13249.

20. Schulz SVW, Laszlo R, Otto S, et al. Feasibility and effects of a combined adjuvant high-intensity interval/strength training in breast cancer patients: a single-center pilot study. Disabil Rehabil. 2018; 40 (13): 1501-08. DOI: 10.1080/09638288.2017.1300688.

21. Mirandola D, Miccinesi G, Muraca MG, et al. Longitudinal assessment of the impact of adapted physical activity on upper limb disability and quality of life in breast cancer survivors from an Italian cohort. Support Care Cancer. 2018; 26 (2): 329-32. DOI: 10.1007/s00520-017-3930-2.

22. Paolucci $\mathrm{T}$, Bernetti $\mathrm{A}$, Paoloni $\mathrm{M}$, et al. Therapeutic alliance in a single versus group rehabilitative setting after breast cancer surgery: psychological profile and performance rehabilitation. Biores Open Access. 2019; 8 (1): 101-10. DOI: 10.1089/ biores.2019.0011.

23. Travier N, Buckland G, Vendrell JJ, et al. Changes in metabolic risk, insulin resistance, leptin and adiponectin following a lifestyle intervention in overweight and obese breast cancer survivors. Eur $\mathrm{J}$ Cancer Care. 2018; 27 (4): e12861. DOI: 10.1111/ecc.12861.

24. Kulik-Parobczy I. Evaluation of the effectiveness of physiotherapy in patients after oncological breast cancer treatment based on spirometric indicators. Contemp Oncol (Pozn). 2019; 23 (1): 4751. DOI: 10.5114/wo.2019.82929.

25. Janssen SMJ, Abbink JJ, Lindeboom R, Vliet Vlieland TPM. Outcomes of pulmonary rehabilitation after treatment for nonsmall cell lung cancer stages I to Illa: an observational study. J Cardiopulm Rehabil Prev. 2017; 37 (1): 65-71. DOI: 10.1097/ HCR.0000000000000227.

26. Edbrooke L, Aranda S, Granger CL, et al. Multidisciplinary homebased rehabilitation in inoperable lung cancer: a randomised controlled trial. Thorax. 2019; 74 (8): 787-96. DOI:10.1136/ thoraxjnl-2018-212996.

27. Peddle-Mclntyre CJ, Singh F, Thomas R, et al. Exercise training for advanced lung cancer. Cochrane Database Syst Rev. 2019; 2 (2): CD012685. DOI: 10.1002/14651858.CD012685.pub2.

28. Batchelor TJP, Rasburn NJ, Abdelnour-Berchtold E, et al. Guidelines for enhanced recovery after lung surgery: recommendations of the enhanced recovery after surgery (ERASVR ) society and the European Society of Thoracic Surgeons (ESTS). Eur J Cardiothorac Surg. 2019; 55 (1): 91-115. DOI: 10.1093/ejcts/ezy301.

29. Olivier C, Grosbois JM, Cortot AB, et al. Real-life feasibility of 
home-based pulmonary rehabilitation in chemotherapy-treated patients with thoracic cancers: a pilot study. BMC Cancer. 2018; 18 (1): 178. DOI: 10.1186/s12885-018-4102-6.

30. Liu X, Wang YQ, Xie J. Effects of breathing exercises on patients with lung cancer. Oncol Nurs Forum. 2019; 46 (3): 303-17. DOI: 10.1188/19.ONF.303-317.

31. Steiner MC. Should pulmonary rehabilitation be a standard of care in lung cancer? Thorax. 2019; 74 (8): 725-6. DOI: 10.1136/ thoraxjnl-2019-213157.

32. Da Silva JR Jr, Wiegert EVM, Oliveira L, Calixto-Lima L. Different methods for diagnosis of sarcopenia and its association with nutritional status and survival in patients with advanced cancer in palliative care. Nutrition. 2018; 60: 48-52. DOI: 10.1016/j. nut.2018.09.003

33. Fukushima T, Nakano J, Ishii S, et al. Factors associated with muscle function in patients with hematologic malignancies undergoing chemotherapy. Support Care Cancer. 2020 Mar; 28 (3): 1433-9. DOI: 10.1007/s00520-019-04955-2.

34. Damlaj M, El Fakih R, Hashmi SK. Evolution of survivorship in lymphoma, myeloma and leukemia: Metamorphosis of the feld into long term follow-up care. Blood Rev. 2019; 3: 63-73. DOl: 10.1016/j.blre.2018.07.003.

35. Hackett F, Dowling M. Lymphoma survivors' experiences at the end of treatment. J Clin Nurs. 2019; 28 (3-4): 400-9. DOl: 10.1111/jocn.14658

36. Raphael D, Frey R, Gott M. Maintaining psychosocial wellbeing for post-treatment haematological cancer survivors: Strategies and potential barriers. Eur J Oncol Nurs. 2019; 38: 36-41. DOl: 10.1016/j.ejon.2018.11.011

37. Hathiramani S, Pettengell R, Moir H, Younis A. Relaxation and exercise in lymphoma survivors (REIL study). BMC Sports Sc Med Rehabil. 2019; 11: 17. DOI: 10.1186/s13102-019-0127-7.

38. Frawley HC, Lin KY, Granger CL, et al. An allied health rehabilitation program for patients following surgery for abdomino-pelvic cancer: a feasibility and pilot clinical study. Support Care Cancer. 2020 Mar; 28 (3): 1335-50. DOI: 10.1007/s00520-019-04931-w.

39. Hegedus A, Trzaskoma L, Soldos P, et al. Adaptation of fatigue affected changes in muscle EMG frequency characteristics for the determination of training load in physical therapy for cancer patients. Pathol Oncol Res. 2020 Apr; 26 (2): 1129-35. DOl: 10.1007/s12253-019-00668-3.

40. Santa Mina D, Au D, Auger LE, et al. Development, implementation, and effects of a cancer center's exercise-oncology program. Cancer. 2019; 125 (19): 3437-47. DOl: 10.1002/cncr.32297.

41. Sharma R, Molinares-Mejia D, Khanna A, et al. Training and practice patterns in cancer rehabilitation: a survey of physiatrists specializing in oncology care. Phys Med Rehab. 2020 Feb; 12 (2): 180-5. DOI: 10.1002/pmrj.12196.

42. Hathiramani S, Pettengell R, Moir H, Younis A. Lymphoma survivors' experience of participation in a home-based intervention post-chemotherapy. Qual Life Res. 2019 Nov; 28 (11): 2951-5. DOI: 10.1007/s11136-019-02244-3.

43. Stubblefield MD, Kendig TD, Khanna A. ReVitalizing cancer survivors - making cancer rehabilitation the standard of care. MD Advis. Spring 2019; 12 (2): 30-33.

44. Stout NL, Silver JK, Alfano CM, et al. Long-term survivorship care after cancer treatment: a new emphasis on the role of rehabilitation services. Phys Ther. 2019; 99 (1): 10-13. DOI: 10.1093/ptj/pzy115.

45. Yadav RR, Ngo-Huang AT, Ng A, et al. Characteristics of cancer rehabilitation fellowship training programs in the USA. J Cancer Educ. 2018; 33 (6): 1364-7. DOI: 10.1007/s13187-018-1371-3.

46. Hutchison N, Deval N, Rabusch S, et al. Physical therapy based exercise protocol for cancer patients: Evaluating outcomes for cardiopulmonary performance and cancer-related fatigue. PM R. 2019 Feb 6. DOI: 10.1002/pmrj.12128. 